Fiftrevista

tats ty

Edilene Coffaci de Lima Maria Inês Smiljanic

Campos 7(1):159-177, 2006.

\section{Júlio Cezar Melatti Etnógrafo e divulgador da Antropologia}

No primeiro ano da década de 1960, Júlio Cezar Melatti, graduado em História e Geografia, começou o Curso de Especialização em Antropologia Cultural, organizado pelos professores Luis de Castro Faria e Roberto Cardoso de Oliveira, que então era oferecido na Universidade Federal do Rio de Janeiro (UFRJ). Dez anos mais tarde, em 1970, concluiria seu doutorado em Antropologia, na Universidade de São Paulo, com seus estudos sobre os Krahó. Ao lado de Roque Laraia, Júlio Cezar Melatti participou da constituição e da consolidação do Departamento de Antropologia da UnB. A docência foi dividida com períodos de pesquisa de campo: entre meados da década de 1970 e meados de 1980, J. C. Melatti dedicou-se especialmente ao trabalho de campo entre os índios Marubo, no vale do Javari. Sua aposentadoria na UnB, em 1994, foi seguida de uma justa homenagem: a distinção de Professor Emérito que the foi concedida em 1999. Pela relevância do conjunto de sua obra para a antropologia e para a etnologia sul-americana, J.C. Melatti foi condecorado com a insígnia de Comendador da Ordem Nacional do Mérito Científico, em 2002.

Como se não bastasse, desde os primeiros anos de sua bem-sucedida carreira de antropólogo, J. C. Melatti preocupou-se com a divulgação da disciplina. $\mathrm{Na}$ UnB empenhava-se na divulgação de textos reproduzidos, boa parte das vezes, em mimeógrafos. Hoje dedica-se, entre outras coisas, a manter acessível sua página eletrônica na internet, onde estão disponíveis muitos de seus escritos, e ao trabalho de sistematização das informações etnográficas sobre os povos ameríndios, estendendo seu projeto, anteriormente restrito à América do Sul, às demais Américas.

A entrevista aconteceu em Curitiba, em 25 de novembro de 2005, quando também fez uma palestra no PPGAS/UFPR intitulada “Memórias da pesquisa entre os Marubo". Para que possamos ir à entrevista, falta apenas dizer que o tamanho de sua contribuição à nossa disciplina contrasta fortemente com a simplicidade de suas palavras sobre sua trajetória. 
Campos: Como foram os primeiros anos de sua formação acadêmica?

Júlio Cezar Melatti: Minha formação acadêmica foi em Geografia e História nas Faculdades Católicas Petropolitanas, nos anos de 1957 a 1960. Tratava-se de um curso seriado, era bacharelado e licenciatura. Tinha a disciplina Antropologia: no primeiro ano era antropologia física; no segundo ano, antropologia cultural; e no terceiro ano, antropologia do Brasil, etnografia do Brasil, uma coisa assim. Minha professora nesse curso foi a Maria Laís Mousinho. Hoje Maria Laís Mousinho Guidi. Ela tinha sido aluna daqueles cursos do Darcy Ribeiro no Rio de Janeiro. Ela deu aulas no primeiro ano, depois no segundo veio um substituto que também tinha sido aluno desses cursos do Darcy Ribeiro, que foi o Marcelo Moretson, e no terceiro ano voltou a Maria Lais. Quando eu já estava terminando a licenciatura, ela falou comigo que havia no Museu Nacional um curso de um professor muito bom, um curso de especialização em Antropologia, que era o do Roberto Cardoso de Oliveira. Ela perguntou por que eu não fazia o exame de seleção. Eu fui, fiz e entrei. Fiz esse curso no ano de 1961. Quando terminei o curso, Roberto Cardoso tinha elaborado dois projetos, não sei qual foi o primeiro, qual o segundo, mas um era o estudo comparativo da organização social de grupos indígenas brasileiros, e o outro era o projeto de fricção interétnica. Ele tinha colocado Krahó nos dois projetos, então me indicou para fazer a parte Krahó e eu fiz. De certa maneira, esse projeto de estudo comparativo de organização social do Cardoso foi incorporado ao projeto Harvard-Brasil Central e então eu passei a participar deste projeto. Foi essa a minha formação. Roberto Cardoso, naquela época, quando nós iniciamos esse curso, dava à pesquisa prioridade sobre a titulação acadêmica mas, atento às novas exigências decorrentes das reformas que então se faziam na universidade brasileira, fez seu doutorado na Universidade de São Paulo e recomendou-nos que o fizéssemos também. Então nós fomos nos inscrever na USP. Era um doutorado sui generis na época, porque eu nunca fiz uma única disciplina na USP, a gente simplesmente se inscrevia e esperava dois anos para defender a tese. Agora, como eu não tinha mestrado, só tinha esse curso de especialização no Museu, tive que apresentar duas teses subsidiárias: uma foi aquele "Índios e Criadores", que foi lido pelo Florestan Fernandes - não havia uma defesa pública, o examinador lia e dava a nota; e a outra foi "O Messianismo Krahó", que foi lida pela Maria Isaura Pereira de Queiroz. Com essas duas notas, eu defendi a tese. Meu orientador foi João Baptista Borges Pereira. Era Egon Schaden, mas ele se aposentou e passou a ser o João Baptista. Em 1970 eu defendi o doutorado. Então acho que todos nós somos assim, doutores pela USP sem termos passado pelas classes, pelas aulas da USP: Cardoso - que lá fez a graduação -, eu, Roque [de Barros Laraia], todos somos doutores pela USP.

Campos: Sua formação em Geografia e História influenciou de alguma forma os caminhos tomados pelo senhor em sua trajetória como antropólogo?

Júlio Cezar Melatti: Deve ter influenciado, não sei responder assim de chofre sobre isso. Para dizer a verdade, entrei no curso por causa de História, mas a história que eu tive no curso não me trouxe nenhuma visão nova. Foi apenas, vamos dizer assim, o detalhamento do meu curso colegial. Era um seriado: o primeiro ano era história antiga 
e medieval - mas eu só tive história antiga, e muito esparsamente, não dava tempo. Então, numa Universidade Católica, não tive história medieval. O segundo ano era história moderna, e o terceiro, história contemporânea. Quem deu história moderna e contemporânea para mim foi o Francisco Falcon. Ele dava aula em várias universidades no Rio de Janeiro - na época os professores davam aula em várias universidades - e eu acredito que o curso que ele deu em Petrópolis foi mais ou menos uma repetição do que ele dava no curso Rio Branco para diplomatas, porque era pura história diplomática. Então a História não me marcou muito. Acho que os professores mais empenhados em dar uma visão nova da sua disciplina eram os professores de Geografia, sobretudo uma professora chamada Maria Madalena Vieira Pinto. Foi ela que criou uma sala de Geografia, trazia revistas, levou a gente para fazer uma pequena pesquisa de campo, de um dia. A Antropologia era uma novidade, eu nunca tinha visto antes. Mas acho que os professores mais empenhados eram os de Geografia, sobretudo a Maria Madalena Vieira Pinto. Ela trazia uma visão nova da disciplina.

Campos: O senhor acha que a sua preocupação de redefinir o conceito de áreas culturais vem da sua formação em Geografia?

Júlio Cezar Melatti: É, pode ser que minha formação em Geografia tenha ajudado a pensar essas áreas. Mas a preocupação em fazer áreas talvez tenha sido até certo retrocesso, sob o ponto de vista da Antropologia. O que eu quis fazer foi simplesmente um trabalho didático. Um trabalho didático sobre indígenas que abarcasse mais que o Brasil. Eu escolhi a América do Sul e como não podia tratar de grupo a grupo tinha que classificá-los, reuni-los e distribuir de alguma maneira. Foi aí que usei este critério de áreas culturais ou etnográficas, no entanto sem uma preocupação maior. Hoje, à medida que este trabalho avança, eu vou desanimando um pouco. Talvez a Geografia tenha ajudado um pouco, mas não foi o principal motor dessa escolha. Foi apenas uma maneira de apresentar, de pegar uma multiplicidade muito grande de sociedades e culturas e agrupá-las de alguma maneira.

Campos: Talvez pensando mais a partir do que Eduardo Galvão e Darcy Ribeiro haviam feito também.

Júlio Cezar Melatti: Até tentei, mas a única inovação que eu imaginara dependeria de muita informação. Preocupavame em não apoiá-las tanto nas semelhanças culturais - por isso as chamei de áreas etnográficas - e mais nas articulações. No entanto, estar atento e ser informado dessas articulações é muito difícil, a não ser sobre a área que a gente conhece pessoalmente. Mas sobre as outras áreas é difícil. A inclusão por Galvão dos Bororos e Canelas na mesma área cultural, do ponto de vista da semelhança cultural, é legítima. Mas um canela tem poucas possibilidades de encontrar um bororo na vida e vice-versa, a não ser hoje nas associações e reuniões indígenas de âmbito nacional. Eles não têm nenhum intercâmbio entre si. São áreas simplesmente baseadas na semelhança, mas não na articulação social. Então a tentativa era também levar um pouco em conta essa articulação: grupos que se procuram, seja para fazer guerra, seja para casamento, seja para procurar auxílio xamânico ou, enfim, fazer 
trocas comerciais ou trocas rituais. Mas é preciso de muita informação e no fim essas áreas acabaram num compromisso de articulação, semelhança cultural e uma porção de coisas mais. Com o tempo elas acabam se fixando também. Os projetos antropológicos acabam definindo e cristalizando essas áreas na mente da gente. Não que elas se cristalizem na realidade, mas um projeto Jê de certa maneira cria toda uma expectativa em torno dos grupos jê e a gente acaba tendo que considerar uma área Jê ou uma área Macro-Jê, o que seja. Outros projetos semelhantes também acabam consagrando certas áreas. Por isso ficaram como áreas etnográficas: são áreas dos etnógrafos, mais do que áreas geográficas, ou áreas culturais, ou áreas de articulação. Então preferi deixar como áreas etnográficas.

Campos: De todo modo, a mudança da terminologia - áreas etnográficas, em lugar de áreas culturais - tinha a ver também com essa divergência conceitual, digamos assim, em relação ao projeto anterior.

Júlio Cezar Melatti: É isso. E foi também para chamar a atenção de que, afinal, a área quem traça é o etnógrafo, ou etnólogo. Acaba sendo traçada por ele segundo as suas conveniências ou princípios teóricos. É desse jeito. É difícil trabalhar com isso porque, por exemplo, se a gente mantém essa área do Galvão, que é a área Tocantins-Xingu, que é a área dos Jê, mais Bororo, mais Karajá também, a gente vê por exemplo que os Canelas têm um intercâmbio muito grande com os Guajajaras que, no caso, estão na área Pindaré-Gurupi do Galvão. No entanto eles estão entrosados, suas terras são uma junto da outra, eles inclusive têm muitos contatos antigos tanto hostis como amistosos. Por exemplo, os Canelas foram chamados a combater os Guajajaras depois da revolta contra os missionários capuchinhos em 1901, e os mesmos Guajajaras é que deram abrigo aos Canelas quando eles tiveram que fugir depois do movimento messiânico em 1963. Então eles estão muito entrosados com os Canelas. No entanto, os Canelas estão numa área cultural e os Guajajaras noutra. A mesma coisa com os Caiapós - que estariam numa área cultural - e os Parakanãs, Arawetés e Assurinis, que estariam em outra, mais Tupi. Mas acontece que eles sempre viveram em conflito, até recentemente, então eles estiveram sempre articulados, naturalmente articulados pela guerra. Considerá-los em áreas diferentes é um tanto estranho, não?

Campos: Segundo Roque de Barros Laraia, em 1968 ele recebeu um convite para trabalhar na Universidade de Brasília e foi-lhe facultada a escolha dos profissionais que viriam a formar o corpo docente em Antropologia na UnB. Ele então convidou vários antropólogos, mas o senhor foi o único que aceitou o convite e, em janeiro de 1969, ambos chegaram a Brasília no mesmo vôo. O que o motivou a ir para Brasília?

Júlio Cezar Melatti: Bem, o Roque teve que tomar uma decisão pessoal mais séria do que eu, porque ele já era do quadro do Museu Nacional, teve que deixar o quadro do Museu Nacional. Eu não, eu era um estagiário. Estava precisando de emprego, então foi uma oportunidade de emprego e eu fui por causa disso. Eu não tinha 
nenhum vínculo com o Museu, a não ser uma bolsa da Universidade Federal do Rio de Janeiro. Então eu fui em busca de uma estabilidade, foi o que me levou para Brasília.

Campos: Em 1968 seu doutorado não estava concluído ainda.

Júlio Cezar Melatti: Não, eu estava inscrito, mas só fui concluir em 1970, quando já estava na Universidade de Brasília.

Campos: Além de Roque Laraia, quem estava lá nessa época?

Júlio Cezar Melatti: A Universidade de Brasília tinha passado por uma segunda crise. Ela teve a crise de 1965, quando saíram muitos professores: uns foram mandados embora e outros em solidariedade pediram demissão, uma coisa assim. E em 1968 passou por uma outra crise também. No departamento em que nós entramos havia vários professores que simplesmente estavam ali ocupando as vagas abertas, alguns não tinham formação. $\mathrm{O}$ departamento não era de Antropologia, era um departamento de Ciências Sociais ou algo mais amplo. Reunia sociólogos, antropólogos, cientistas políticos. Então, de Antropologia mesmo, nós só encontramos um professor lá, que era um cineasta, Geraldo Morais. Ele até continuou com a gente. Depois ele resolveu se transferir para o departamento de cinema ou que agregava a área de cinema. Então, a princípio, de Antropologia, só ficamos eu e o Roque. Havia na área de Sociologia vários professores que depois foram demitidos e o Roque providenciou contratações novas de professores que tinham currículo mais ligado à Sociologia. A mesma coisa aconteceu com [Ciência] Política. Posteriormente vieram outros professores de Antropologia, não sei a ordem, mas acho que Eurípedes da Cunha Dias foi a primeira, ela deve ter chegado em 1970 ou 1971. Depois chegou a Mireya Soares, que era casada com o Gláucio Soares. Em 1972 o próprio Cardoso foi para lá, foi criar o mestrado. Foi dessa maneira. Eu e o Roque fomos contratados juntos. Embora nós tenhamos chegado quando o mês de janeiro já transcorria, o nosso contrato é de 10 de janeiro de 1969.

Campos: Como foi participar da constituição e consolidação desse departamento que mais tarde veio a ser tão reconhecido?

Júlio Cezar Melatti: Não sei como eu vou dizer, havia uma série de coisas que se faziam na Universidade de Brasília. Inclusive nós tínhamos um setor de mecanografia que reproduzia qualquer livro e distribuía de graça para os estudantes. O Fernando Henrique [Cardoso] que não nos ouça, mas aquele livro que ele organizou com o Otávio lanni, Homem e Sociedade, acho que praticamente todos os capítulos foram devidamente reproduzidos na mecanografia do Instituto [de Ciências Sociais] e vários outros textos também. Distribuía-se de graça, depois é que as coisas foram se disciplinando e se pensou, por exemplo, que a biblioteca podia ter mais exemplares 
de um mesmo livro. Foi um período assim de organizar os textos na biblioteca, remanejar os professores, trazer professores novos. Isso foi no período de 1969 a 1972.

Campos: Nessa época a pesquisa de campo com os Krahó estava concluída?

Júlio Cezar Melatti: Eu tinha feito pesquisa de campo com os Krahós até 1967. Com esse material que colhi - eu fui em 1962, 1963, 1964 e duas vezes em 1967 - eu fiz a tese. Apresentei a tese em 1970. Depois ainda fui lá mais uma vez em 1971. Fui com a tese na mão, conferi umas coisas, colhi mais dados. Foi o tempo em que nós conseguimos uma verba da própria universidade, acho que foi a única vez que a Universidade de Brasília deu ela própria dinheiro para pesquisa etnográfica. Conseguimos dinheiro para o Heinz Forthmann fazer o filme sobre os Krahós. Muita coisa ele fez com recursos próprios. Levou seu próprio equipamento, levou o seu próprio filme, que era pouco. Ele fez o filme, depois voltamos, ele ficou montando o filme. Era demorado, dependia de mais recursos. Foi então que ele sofreu um assalto no Rio de Janeiro e parece que brigou com o assaltante, apanhou, pegou um coágulo no sangue, uma coisa qualquer assim, de uma série de pancadas, e ele ficou com a vida meio perigando. Não sei se ele acabou morrendo disso, poucos anos depois, e o filme ficou inacabado. Então o filme veio a ser acabado, a montagem e tudo mais, por um aluno dele, Marcos de Souza Mendes, muitos anos depois. Foi a última vez que eu fiz pesquisa com Krahó. Foi em 1971, depois da defesa da tese.

Campos: De todo modo era um período muito intenso, porque ao mesmo tempo o senhor estava na UnB, ajudando a constituir o departamento, fazendo pesquisa de campo e o trabalho do doutorado.

Júlio Cezar Melatti: É, eu tenho períodos de trabalho intenso e outros períodos assim meio mornos, quase letárgicos. Assim, nesse período, no começo da Universidade de Brasília, eu não só estava lá, como eu fiz a tese, terminei lá. Também terminei o Índios do Brasil - eu tinha começado no Museu Nacional, mas terminei lá. O Messianismo Krahó, eu fiz lá. Então uma boa parte do que eu fiz está nessa passagem dos anos 1960 para a década de 1970, por aí. Depois eu descansei.

Campos: Sua trajetória acadêmica é marcada pela preocupação em divulgar a Antropologia para um público mais amplo e tornar acessíveis ao público especializado os trabalhos de outros autores. Assim, o senhor foi responsável pela edição da revista Pesquisa Antropológica, participou da publicação da revista Atualidade Indígena, de uma coluna de Antropologia no Jornal de Brasília, do Anuário Antropológico e, mais recentemente, da Enciclopédia dos Povos Indígenas do Instituto Socioambiental. Além disso, o senhor ministra regularmente cursos de extensão na UnB. O senhor poderia falar um pouco sobre estes trabalhos?

Júlio Cezar Melatti: O primeiro foi um livro, Índios do Brasil. Eu pensei nisso ainda no Museu Nacional e comecei a fazer lá. Quando mudei para Brasília, continuei trabalhando e ele saiu em 1970. Foi um livro que fez sucesso. Talvez 
tenha sido a única publicação minha que teve um interesse maior dos leitores e isso me motivou a ficar trabalhando um pouco nessa área. Com Alcida Ramos, entre 1973 e 1974, para facilitar a leitura nos cursos introdutórios de Antropologia, nós fizemos os Cadernos de Antropologia, que eram traduções. Chegamos a fazer oito publicações, oito artigos traduzidos, que eram impressos em multilite pelo Summer Institute of Linguistics. A gente pedia licença ao autor, pedia licença à revista, alegava que era para alunos, que eram textos didáticos etc., se eles poderiam dispensar do pagamento de direitos autorais. Geralmente eles dispensavam, então entregávamos a alguém para traduzir e fazíamos a revisão. Então saía com uma página de crédito, direitinho: traduzido de tal lugar, com a autorização, com o ano etc. Fizemos sete assim. Depois acho que foi o Decanato de Extensão que resolveu republicá-los com o nome de Textos de Aula e aí até foi acrescentado um oitavo texto. Os Cadernos de Antropologia publicaram, nessa ordem: "A Família é Universal”, do Melford Spiro; “Regras de Residência”, do [Ward H.] Goodenough; "A Noção de Bruxaria como Explicação de Infortúnios", do Evans-Pritchard; "Rituais de Rebelião no Sudeste da África”, de Max Gluckman; "Sucessão à Chefia em Tikopia", de [Raymond] Firth; "O Ciclo de Desenvolvimento do Grupo Doméstico", do Meyer Fortes; "Parentesco, Amizade e Relações Patronos-Clientes nas Sociedades Complexas”, do Eric Wolf; e o oitavo, esse que só saiu depois, "Causalidade e Leis Culturais", do Julian Steward.

Um pouco depois eu trabalhei como colaborador na Revista de Atualidade Indígena, num período político ainda bastante pesado. Algumas pessoas não viam com bons olhos o fato de eu estar trabalhando com essa publicação na Funai - mas eu não trabalhava lá, eu dava uma colaboração. Isso foi no tempo dos militares. Na Revista de Atualidade Indígena, cujo primeiro número saiu em 1976, eu publiquei alguns artigos e até dei a idéia de em cada número eles fazerem uma ficha de um grupo indígena, que saía na última página. Trazia alguma informação, uma espécie de enciclopédia para guardar em caixa de sapato, a idéia era essa. Então em cada número saía a informação sobre um grupo indígena. Depois eu fiz também uma bibliografia que saiu área por área - as áreas do Galvão. O editor da Revista veio um dia me comunicar muito contente que, apesar de eu ter colocado os livros do Darcy Ribeiro, a direção da Funai tinha permitido pôr o nome de Darcy Ribeiro na Revista. Para vocês verem como eram as coisas. Eu também bolava uns testes, umas perguntas escolares para sair na revista. A Revista de Atualidade Indígena era uma revista assim do formato da Veja ou da IstoÉ, mas antes a Funai publicava uma outra chamada Informativo Funai. Acho que eu tenho dois ou três artigos no Informativo Funai. Depois alguns deles foram republicados na Revista de Atualidade Indígena. Ela era vendida em jornaleiro, tinha divulgação.

Simultaneamente, ou depois, junto com o Martín Ibáñez Novión, fizemos a Pesquisa Antropológica, que era uma revista, um folheto mimeografado. Foi um tempo em que todas as revistas de Antropologia estavam atrasadas - as que existiam: a Revista do Museu Paulista e a Revista de Antropologia. Então nós pensamos em fazer um boletim que desse conta de pesquisas em andamento, resenhas, notícias. Fizemos isso que seria um boletim mensal - claro que depois do terceiro ou quarto o mensal começou a fraquejar um pouco, mas fizemos quinze números. A partir do número 16 nós tomamos uma decisão que talvez não tenha sido muito sábia, mas achamos que devíamos publicar as teses de mestrado em vez de ficar fazendo noticiário. Hoje não pensaríamos mais nisso, claro, não daríamos conta. Mas, então, saíram algumas teses de mestrado na Pesquisa Antropológica. 
Nos anos de 1983 e 1984 funcionou em Brasília uma regional da Associação Brasileira de Antropologia. Rafael Bastos foi o diretor. A regional conseguiu no Jornal de Brasília um espaço para publicar semanalmente uma coluna. De 9 de julho de 1983 até 24 de junho de 1984 nós publicamos 45 colunas no Jornal de Brasília, escritas por autores diferentes, autores que eram convidados, até intimados a escrever. Quem fazia isso junto comigo era a Custódia Selma Sena do Amaral, que na época era aluna da pós-graduação em Brasília e hoje é professora na Universidade Federal de Goiás. Nós tínhamos que convidar alguém para escrever, para sair na sextas-feiras, ou era até sexta-feira que a gente tinha que entregar. Eu sei que tinha um momento assim que, se não fosse até as 3 horas da tarde, se não entregássemos naquele dia da semana, a coluna não saía. Então às vezes a pessoa estava acabando de datilografar e a gente estava ali para levar e sair correndo para o jornal. Entregamos essas 45 colunas nesse tempo. Então foi um período bom, esse. E tem os cursos à distância.

Houve um momento, eu não sei precisar o ano, em que o Decanato de Extensão estava sendo dirigido pelo professor [Carlos Henrique] Cardim, que era um professor de política, um diplomata também, e ele deu uma força muito grande à editora. E ele pensou, junto com os seus auxiliares, num curso de Antropologia à distância. Seria uma coleção de textos. E pediu ao nosso departamento para colaborar. Então nós pensamos: porque nós vamos montar um curso de Antropologia à distância se nossos alunos regulares estão precisando de textos aqui? Vamos montar um curso sim, de Antropologia à distância, mas com textos que sirvam também para serem utilizados pelos nossos alunos regulares. Tempos depois o Decanato tinha tomado uma outra direção, já havia desistido da coleção, e ficamos com cinco textos prontos. Um era do Roque Laraia, aquele texto sobre cultura, que ele então publicou na Série Antropologia e depois pela Jorge Zahar e que continua saindo, está chegando quase na vigésima edição. Outro é o da Alcida Ramos, "Sociedades Indígenas", que também saiu na Série Antropologia do departamento e depois pela Ática, já tem mais de uma edição também. Um outro foi do Carlos Brandão, um texto sobre contato que ele publicou pela Brasiliense. O outro foi do Rubem Oliven, que então saiu na Pesquisa Antropológica e depois na editora Vozes. E havia um texto meu sobre a Antropologia no Brasil que eu pus na Série Antropologia também e que saiu depois no BIB 17. Então todo mundo que atendeu ao nosso pedido acabou publicando, não saiu a coleção, mas acabou publicando.

Finalmente temos esses cursos de extensão que eu dou na Universidade de Brasília: um sobre as áreas etnográficas e outro de mitologia indígena. E tem meu trabalho no Instituto Socioambiental. No início da década de 1980 eu tinha colaborado na coleção Povos Indígenas no Brasil do CEDI [Centro Ecumênico de Documentação e Informação, que mais tarde daria origem ao ISA], que era uma coleção de dezoito volumes. Eu participei e fui organizador de um volume, do Javari. Saíram mais uns dois ou três volumes e eu acho que o do Javari saiu porque eu estava quase sozinho trabalhando nisso. Então, como o Javari era uma área onde praticamente não tinha ninguém, só a Delvair Montagner e eu, foi fácil de fazer. Embora os dados fossem muito sumários, deu para fazer. Mas outros não. Depois o Instituto lançou o Aconteceu, com recortes de jornais e dados sobre população, terras e tal, lançou de cinco em cinco anos. Posteriormente promoveu uma reunião, apareceram várias pessoas, sobre uma coleção, uma enciclopédia, seria meia dúzia de volumes: um volume seria de etnias, outro seria mais 
histórico, um outro volume seria mais de conceitos: o que é cultura, o que é sociedade, o que é parentesco, o que é isso, o que é aquilo. Mas aí essa idéia ficou no ar, não foi levada adiante e quando se aproximava o ano 2000, que seria o quinto centenário da descoberta do Brasil, o Instituto Socioambiental pensou em pelo menos lançar o volume das etnias para marcar a data. E me convidaram para coordenar o volume, o que fiz no escritório do ISA em Brasília, em 1998 e 1999. Nós começamos a convidar pessoas para escrever, mas não deu certo. O tempo era mesmo pouco, não dava, e depois a resposta deixou muito a desejar: além das que colaboraram, nós tivemos as pessoas que se negavam e as pessoas que aceitavam e não faziam, essas são as piores. Então eu fiquei lá dois anos e entreguei sem terminar. E ao mesmo tempo o computador começava a apresentar mais recursos. Pensamos: ao invés de imprimir, por que não fazer um CD-Rom? É mais fácil. Mas não seria tão fácil, porque um CD-Rom completo seria praticamente uma edição também. Daria tanto trabalho quanto uma edição de um livro impresso. Aí começou a aparecer a internet, decidimos lançar na internet. À medida que vai ficando pronto, lançase a informação. Foi essa a idéia que pegou. Quando eu saí já tinha talvez uns quarenta verbetes na internet. $O$ pessoal do ISA continuou e continua até hoje. Quer dizer, uma coisa que era para terminar no ano 2000 ainda não terminou. Então eu continuo colaborando informalmente lá, eles de vez em quando me mandam um texto para dar uns palpites, para fazer uma revisão.

E finalmente eu fiz essa minha página na internet com o material que eu tinha, aquele das áreas culturais, das áreas etnográficas. Também trabalhos velhos e outras coisas assim, fui jogando tudo lá e continuo alimentando esse meu site. E tem alguma resposta, de vez em quando eu recebo mensagens com algumas perguntas interessantes e outras um tanto gozadas, como: "Diga-me tudo sobre os Timbira". É o tipo de consulta que me fazem de vez em quando. Uma outra muito gozada foi aquela: "A professora me mandou ler Carnavais, Malandros e Heróis do Roberto Da Matta e eu não estou entendendo nada, me ajude por favor" [risos]. Mas tem outras que são perguntas possíveis de responder.

Campos: O que significa para o senhor o estudo do parentesco no âmbito de suas pesquisas antropológicas?

Júlio Cezar Melatti: Eu não sei porque me interessei por parentesco, talvez porque na época em que eu comecei a estudar no Museu Nacional, e mesmo depois, o parentesco era a chave de tudo. Então a gente atacava pelo parentesco. Lá nos Krahós eu comecei por aí. Afinal, além do projeto de fricção interétnica, o outro, o projeto de Harvard, era sobre organização social, estrutura social, então tinha que entrar pelo parentesco. Esse viés eu levei para a pesquisa Marubo também. É a melhor porta de entrada mesmo, porque quando a gente não tem familiaridade com nada, ao chegar a um grupo, acho que o melhor é fazer recenseamento, ver como é que se compõe a casa, quem mora com quem, e tomar genealogias e o parentesco. Não é só nos meus trabalhos que o parentesco tem importância grande, mas em todos os trabalhos desse período. Inclusive, na Universidade de Brasília, a disciplina parentesco continua sendo obrigatória. Eu acho que no Museu Nacional não é. Em outros cursos não sei. 
Campos: Na pós-graduação ou na graduação?

Júlio Cezar Melatti: Na pós. Então é uma porta de entrada boa, não é?

Campos: "Um Sistema Australiano na Amazônia" é seu primeiro artigo sobre os Marubo. Como o senhor chegou a perceber a 'originalidade' do sistema de parentesco dos Marubo no panorama amazônico e se dispôs a descrevê-lo?

Júlio Cezar Melatti: Quando eu fui a primeira vez para os Marubos, eu e a Delvair, um missionário que já estava lá havia doze anos - ele está lá até hoje, o John Jahsma - nos disse: “Marubo não é um nome, pelo menos não é um nome deles, uma autodenominação. Eles não têm uma autodenominação, mas eles têm uns nomes entre eles, não sei se são clãs, o que é. E o interessante é que o filho não tem nem o nome do grupo do pai, nem o do grupo da mãe: o filho já é de um outro grupo". Então eu fui com as genealogias, comecei a perguntar e comecei a me dar conta que o filho não recebia nem a denominação do grupo do pai e nem a do da mãe, mas esta aparecia na geração seguinte, pulando gerações ela se repetia. Então já deu a cara de Austrália. Só que nos Marubos tinha dois elementos complicadores: um é que as seções não são em número de quatro e nem de oito, não era nem Kariera, nem Aranda; e depois havia seções diferentes com o mesmo nome. O nome Iskonáwavo aparecia em várias linhas matrilineares diferentes. Por exemplo, na linha Varináwavo-Tamaoávo, a seção Tamaoávo também era chamada de Iskonáwavo. Em outra linha, Shanenáwavo, era complementada por Iskonáwavo também. E havia mais umas duas ou três unidades matrilineares em que sempre Iskonáwavo era uma das seções, era um nome alternativo de um outro que eles não diziam logo na primeira vez. Então o difícil foi pegar isso, porque Iskonáwavo estava tão espalhado, alternado com tantos outros nomes. Mas sempre havia um segundo nome. E foi com genealogia que isso foi resolvido, de certa maneira. Os nomes das seções pulavam gerações, e os nomes pessoais também passavam assim. O ideal era passar do pai do pai para o neto, ou então passar da mãe da mãe para a neta, mas é claro que não era sempre assim - mas o ideal era assim, e também a terminologia de parentesco. A terminologia de parentesco também apontava para isso porque, por exemplo, na geração de ego, o irmão mais velho é otxi, mas o pai do pai é ochtxo, enfim, uma variação de otxi, e assim ocorria com outros termos também. A prima cruzada é pano, mas a mãe do pai, paũtxo, derivação de pano. A terminologia de parentesco, os nomes das seções e a transmissão dos nomes pessoais, tudo levava a essas gerações alternadas, características do sistema australiano. Eu trouxe essas coisas e aí fizemos um relatório, eu e a Delvair, que saiu na Série Antropologia depois. O Anuário estava para ser lançado, o primeiro, o Anuário Antropológico/76, que saiu em 1977. Eu então comecei a juntar esses dados e escrevi. A Alcida Ramos me ajudou fazendo uma crítica do texto, estimulou-me também a publicar e eu publiquei. Então foi uma coisa que saiu logo após a primeira etapa de campo, que foi a melhor, a que produziu mais coisas. 
Campos: Depois que a etnologia Pano se constitui, ele se torna uma referência bastante significativa.

Júlio Cezar Melatti: É, mas a existência desse sistema de seções não era uma novidade, uma vez que, eu acho, o sistema Kaxinawá já era conhecido. Acho que o [Kenneth] Kensinger já estava publicando há um tempão.

Campos: Mas o sistema Kaxinawá é mais fechado, homogêneo. As metades são duas, as seções são quatro...

Júlio Cezar Melatti: É, ele é mais nítido. Ele tem as quatro seções, apesar dessa complicação de nomes. Uma mesma seção para mulheres tem um nome e para homens tem outro, então parecem oito, mas são quatro.

Campos: O conjunto de sua obra é um exemplo de como uma etnografia acurada, a despeito dos modismos teóricos, pode fornecer contribuições importantes à Antropologia. Como observaram Aparecida Vilaça e Marcela Coelho na entrevista que o senhor concedeu à revista Mana, sua análise do parentesco Krahó antecipou muitas das discussões atuais sobre parentesco e a constituição da pessoa. Da mesma forma, fazendo uma leitura retrospectiva de sua obra, podemos considerar que seus textos O Messianismo Krahó e Reflexões sobre Algumas Narrativas Krahó são trabalhos inovadores que procuram, a partir da análise dos ritos e mitos, compreender como os Krahó interpretam os eventos históricos. Qual foi a aceitação destes dois trabalhos pelo público especializado naquela ocasião e que leitura o senhor faz hoje destes textos?

Júlio Cezar Melatti: É, o messianismo Krahó é uma coisa inesperada, quer dizer, o movimento tinha ocorrido talvez dez anos antes de eu chegar aos Krahós. Eu não ouvi falar nada na minha primeira etapa, só ouvi falar na segunda, e era uma coisa só do conhecimento deles, não tinha extravasado. Tinha ocorrido e tinha ficado entre eles. Foi diferente do [messianismo] Canela. Com os Canelas houve choque com os fazendeiros, aquela coisa toda. Mas com os Krahós não, ficou ali. Quer dizer, quando o profeta fracassou nas suas previsões, a coisa ficou ali. Então foi por acaso que descobri. Eu tinha recebido um nome na vez anterior que eu havia estado lá, o nome de uma pessoa, de um indígena, então aquela pessoa era considerada meu keti, ou meu tio. Um índio me disse: "Você é maluco, porque seu tio também é maluco, você é maluco". Por que ele é maluco? "Uma vez ele mandou a gente amarrar a boca de todos os cachorros." Bom, aí eu falei: e vocês amarraram? "Amarramos." Então ele é maluco, mas vocês amarraram, por que é que vocês amarraram? "Porque ele estava conversando com a chuva e a chuva quando vinha não podia ouvir os cachorros latirem." E ele foi soltando a história e tal. Então saiu, foi uma coisa assim, inesperada. E quando eu vi esse material eu resolvi mais tarde escrever. Aí comecei a tomar outros depoimentos e tudo. Com O Messianismo Krahó aconteceu comigo o mesmo que aconteceu depois com o próprio Ritos de uma Tribo Timbira. Foi um livro, acho, mal distribuído. O livro foi publicado por uma editora chamada Herder, que depois passou a ter o nome de E.P.U., Editora Pedagógica Universitária. Eu nem sei se ainda existe. Esse livro saiu em 1972. Poucos anos depois me escreveram dizendo que iam vender a edição como 
papel velho. Eles não me tinham pagado nem os direitos autorais, aí eu me ofereci para comprar a edição, era um preço barato. Eu pedi que me mandassem pelo menos os direitos autorais em exemplares. Eles me deram apenas os direitos. Toda a edição virou papel velho, me deram só os meus direitos autorais. Então nessa época eu publicava com o Martín [lbáñez Novión] a Pesquisa Antropológica, e junto com a revista nós demos de brinde o livro aos assinantes. Acho que aí é que ele ficou conhecido. Não antes, quando saiu. Com Ritos de uma Tribo Timbira aconteceu a mesma coisa. Só que ele foi publicado pela Ática, que distribuiu direitinho e tal, pagou os direitos autorais e tudo. Mas confesso que acho o livro meio chato. Além disso, era caro. Apesar de não vender muito a Ática subiu o preço dele todos os anos. Então, não sei exatamente quando, mas nos anos 1990, a Ática disse que ia também vender o livro como papel velho. Ele vendia seis exemplares por semestre. Acho que um por mês. Vendia um por mês, mas o preço dele era, vamos dizer assim, era quase $\mathrm{R} \$ 50$ hoje. Um livro de 1978, ser vendido nos anos 90 pelo preço de um livro novo, não tinha condição. Aí eu pedi, vocês não podem me dar a edição, eles me deram. Aí eu recebi novecentos exemplares. Eu fiquei com uns quatrocentos e deixei o restante. Já que a Ática fica em São Paulo, pedi para entregar no ISA, para o ISA também distribuir. E fiquei distribuindo, parece que ficou sendo mais conhecido também. Então, voltando àquela pergunta de por que eu tenho interesse pela divulgação, é porque eu acho que foi onde eu dei certo. $O$ único livro que saiu, que teve oito edições - teve uma edição em espanhol - foi Índios do Brasil. Este teve divulgação, os outros foram vendidos como papel velho, por isso eu peguei esses livros e pus na internet.

Campos: O retorno tem sido maior, agora que eles estão disponíveis na internet?

Júlio Cezar Melatti: Bom, aí eu só posso avaliar por correspondência, porque não tenho procurado o número de acessos. E depois eu não sei se o acesso foi por causa deles ou por causa de outros textos também incluídos no site. Mas percebi que publicar na internet em $\mathrm{htm} /$ não é muito bom, porque se imprimir aquilo sai muito grande, sai com aquelas margens de internet. O melhor mesmo é pôr na internet sim, mas pôr em pdf. Só que o site que eu uso, gratuito, não aceita $p d f$. Tem que publicar assim. Mas estou pondo algumas coisas em $p d f$, vou colocar tudo em CD-Rom, a quem me pedir eu mando. Acho que foi um pouco em função deste convite de vir aqui a Curitiba que eu peguei o relatório dos Marubos, que está na Série Antropologia, escaneei tudo, fiz a revisão, passei para pdf e pus no site da UnB. Está lá. O outro que eu fiz também foi aquele trabalho sobre o mito Wenía, o mito de origem da cultura Marubo, que saiu também na Série Antropologia. Escaneei, tirei aquela numeração horrorosa que eu não sei por que pus, não tem sentido nenhum, tirei aquilo e está lá no site. Mas eu estava respondendo o quê?

Campos: Sobre a aceitação do seu trabalho.

Júlio Cezar Melatti: É, então, ele tem, deve ter, as pessoas não falam, mas eu não sei assim dizer em números, parece que compradores dos meus livros tem muito poucos. 
Campos: De qualquer maneira a recepção acadêmica que seu trabalhos tiveram é significativa.

Júlio Cezar Melatti: Tem uma resenha do Roberto Da Matta, só que a revista também não é uma revista de grande circulação. Tem uma resenha do Matta na revista Comentário, que é uma revista da comunidade judaica do Rio de Janeiro. Aliás o Matta tem várias coisas lá, na história do Matta a Comentário está muito presente. Acho que aquele trabalho sobre os contos de Edgar Allan Poe, "O Gato Preto" e "O Diabo no Campanário", [saiu lá]. Ele tem a resenha do Messianismo lá. Depois saiu uma outra resenha no BIB, alguém comentou O Messianismo Krahó junto com o trabalho da Manuela Carneiro da Cunha. Então alguém leu [risos].

Campos: Em sua página na internet, o senhor diz que exerceu a tarefa de auxiliar na pesquisa de campo de Roberto DaMatta entre os índios Gaviões do Pará em 1961. Entre 1962 e 1971 fez várias etapas de campo entre os Krahós. Entre 1974 e 1983, fez pesquisa entre os Marubos no vale do Javari. A diversidade da sua experiência de campo poderia favorecer algum tipo de comparação? Quais são as dicas que o senhor pode sugerir?

Júlio Cezar Melatti: Acho que sim, quer dizer, a gente não compara por comparar, só compara quando tem um motivo para isso. Eu não tenho nenhum trabalho, nem vou fazer, de comparação de Krahó com Marubo. São tão diferentes! Para comparar é preciso encontrar alguma semelhança. Então não sei se as dicas vão além daquele texto do método de comparação controlada, clássico, de Fred Eggan. Eu não vou além dele. Um outro que também falou alguma coisa sobre comparação foi Radcliffe-Brown. Eu não sei de autores mais recentes, deve ter. Ou seja: a comparação, pela simples comparação, não sei se leva a alguma coisa.

Campos: A comparação como obrigação.

Júlio Cezar Melatti: É, mas não pode ser. Teria que ter um motivo. Quando a gente compara? Quando encontra grupos que têm uma origem comum, têm instituições semelhantes que, se comparadas, possam revelar alguma coisa nova. Se não for assim, não tem por quê comparar. Eu não fiz a pesquisa entre os Marubos com o objetivo de comparar com a pesquisa anterior. Foi mais um afastamento. Talvez até uma fuga dos Krahós, não sei, por vários motivos [risos]. Para me livrar um pouco do assédio, dos pedidos dos Krahós. E também por certa saturação de pesquisadores, indigenistas, eles estavam começando a marcar presença nos Krahós. Então para clarear um pouco eu fui para os Marubos, até por uma sugestão do Roberto Cardoso. O Roberto Cardoso, numa das suas pesquisas de campo com os Ticuna, no posto de Umariaçu, que era o único posto indígena naquela época nos Ticuna, viu quatro Marubos hospedados lá. Ele gostou muito dos Marubos, ficou encantado e sugeriu que eu deveria fazer pesquisa entre eles. Eu fiquei com aquela idéia na cabeça e mais adiante fui. Talvez tenha sido uma má escolha, como aquele negócio dos mitos indígenas, de escolher entre a espingarda e o arco. Talvez eu tenha escolhido errado, mas fui. Se eu tivesse ficado com Krahó talvez tivesse começado a mostrar um rendimento bem maior. Eu 
conhecia mais Krahó. Ficou por fazer render mais os dados Krahó, e [o trabalho sobre os] Marubo também ficou pela metade.

Campos: De qualquer modo todos os pesquisadores que o sucederam, seja entre os Krahó, seja entre os Marubo, têm uma grande dívida com o seu trabalho. Quando penso nos Krahó, penso nos agradecimentos de Manuela Carneiro da Cunha a sua etnografia, anteriormente à chegada dela lá. E pensando não só nos Marubo, mas em todo o vale do Javari, Philippe Erikson, Javier Ruedas e vários outros pesquisadores que o sucederam também são devedores de seu trabalho.

Júlio Cezar Melatti: Eles também me devem outra coisa, o trabalho chato de assinar no CNPq.

Campos: O senhor está falando de Philippe Erikson e Javier Ruedas, que tiveram que ter tutores no Brasil.

Júlio Cezar Melatti: É, é um negócio esquisitíssimo. É o trabalho de um despachante ou de um fiador. Os estrangeiros têm que ter um despachante ou um fiador. E sempre dá um problema. É difícil, incomoda um pouco. No caso do Ruedas, por exemplo, tinha a consulta à comunidade indígena - e a gente nunca sabe se a consulta é realmente feita ou não. Então foi feita a consulta e aí veio a resposta que a comunidade indígena tinha declarado que não concordava com a pesquisa. Eu tive que fazer uma carta ao presidente da Funai, não me lembro mais quem era, explicando que eu já havia estado lá naquela região, sabia que os Marubos ficavam distantes da sede da Funai e que dificilmente a Funai local ia alugar um barco, pagar a despesa de um barco para fazer consulta a cada comunidade para ver se queriam um antropólogo lá ou não. Sugeri então que a Funai desse uma licença precária a ele. Ele iria com uma licença precária, se os índios reclamassem a Funai tomaria as providências. Dias depois veio a resposta: a comunidade tinha aceito a pesquisa, rapidinho. São situações chatas, mas eu faço isso. Fiz para o Ruedas, fiz para o Erikson e faço constantemente para o William Crocker, para ele ir aos Canelas. 0 William Crocker tem um plano de acompanhá-los pelo resto da vida. De dois em dois anos, ele visita os Canelas. Ele fez 81 anos agora e vai lá.

Campos: Qual parentesco, além do lingüístico, o senhor arrisca dizer que existe entre os Marubo e os Katukina?

Júlio Cezar Melatti: O que a gente nota, você sabe disso, é que tem uns grupos dos Katukina que são como as seções Marubo, ao menos têm os mesmos nomes. Parece que têm alguns episódios mitológicos em comum também. Daí a preocupação de Marubo e Katukina em resolver o problema da travessia da ponte-jacaré: quem ficou de um lado, quem ficou do outro, quem atravessou, quem não atravessou. E eu acho que isso está muito ligado ao fato - talvez um pouco desconhecido, mas na tese do Ruedas isso é bem ilustrado - de que os Marubos são uma porção de grupos que se desorganizaram. Que viveriam ali, no alto Ituí, alto Curuçá, alto Javari e que, com a entrada dos seringueiros e caucheiros, foram dizimados, foram reduzidos, e aqueles que conseguiram 
escapar foram se recolhendo para uma só região, dirigidos por um líder que estava muito preocupado com isso, que era conhecido, João Tuxaua. Ele foi agregando essas pessoas, juntou todos de novo ali e eles vieram a ser os Marubos. Ruedas na sua tese faz uma reconstituição disto, ele conseguiu o depoimento dos índios do Maronal sobre quem veio de onde, de que rio, como foram se reunindo no alto Maronal. É possível que grupos de nomes semelhantes estejam em parte nos Marubos, em parte nos Katukinas, organizados de modos um tanto diferentes. Talvez - quem sabe? - eles tenham vivido sempre assim. Claro que a entrada dos seringueiros e caucheiros foi uma coisa muito severa, muito agressiva, mas é bem provável que ao longo da história deles, mesmo antes do contato com os brancos, os grupos se agregavam e se desagregavam. Pode ser que houvesse grupos com quatro seções que em situações de dificuldade se reunissem a outro grupo, depois se separassem de novo. Isto provavelmente deve ter sido assim no passado, um sistema que teria uma certa flexibilidade, e nós estamos vendo apenas os últimos resultados disso.

Campos: Atualmente, alguns antropólogos deixaram de valorizar a pesquisa de campo. Pode-se dizer que a pesquisa de campo está deixando de ser importante ou ela está se reestruturando e se renovando? Se sim, quais os aspectos mais expressivos?

Júlio Cezar Melatti: O campo é indispensável, é uma fonte de renovação da Antropologia. Acho que continua sendo algo valioso. Claro que uns têm mais aptidão para o campo e outros não. Quando a pessoa não tem aptidão para o campo, mas tem algo a dizer, como é o caso do Lévi-Strauss, pode fazer sua carreira toda sem campo. E pode fazer bem. Outros, não. Tem pessoas que fazem muito campo e não resolvem muito, são pessoas que só acumulam, só juntam dados. Varia muito, individualmente. É claro que aqui nós estamos falando de campo de uma maneira geral, não estamos falando só de índios. Nem só de índios não aculturados, porque até hoje muitos antropólogos estrangeiros chegam ao Brasil para fazer pesquisa com índios com pouco contato. É curioso notar que, como os índios norte-americanos já têm muito contato, é claro que se continua a fazer trabalho sobre eles, mas já não figuram mais na bibliografia dos cursos de Antropologia. Acho que o mestrado no Brasil começou muito bem. Mas quando começaram a criar os doutorados, o mestrado se amesquinhou, virou uma etapa do doutorado e hoje a gente vê que o aluno do mestrado não tem tempo para fazer uma pesquisa de campo. Ele tem que fazer uma pesquisa bibliográfica para depois se preparar para o doutorado. No passado às vezes ocorria o oposto, 0 aluno fazia um mestrado tão bom que depois não conseguia superar o mestrado. Então se tem tentado fazer uma coisa só, talvez seja a melhor escolha: começar a pós-graduação e ir direto para o doutorado, sem mestrado. Mas parece que é ainda difícil convencer as fontes financiadoras de bolsa a aceitar essa idéia. Seria o melhor a fazer, acho que mestrado já não tem mais sentido.

Campos: No fim dos anos 60 e inícios dos anos 70, as informações sobre a situação dos povos indígenas situados no Brasil ocuparam um espaço privilegiado na mídia, o que contribuiu para diminuir a distância entre estas sociedades 
e o público mais amplo. Hoje o número de monografias sobre os povos indígenas se multiplicou e a etnologia indígena se especializou. Como o senhor avalia as mudanças operadas na disciplina? O senhor considera que essas mudanças colocam novos desafios ao etnólogo como educador e como cidadão?

Júlio Cezar Melatti: Acredito que sim. Até uns tempos atrás a gente falava pelos índios. Eu me lembro que quando comecei na Universidade de Brasília, quando ocorria algum conflito, alguma coisa qualquer em algum grupo indígena, aparecia um jornalista na Universidade para me perguntar: "O que o senhor acha que vai acontecer, o senhor tem mais informações para me dar sobre esse caso?". Eu respondia: estou esperando para ler no seu jornal. Ele queria que eu, na Universidade de Brasília, soubesse o que estava acontecendo lá. De onde eu ia retirar a informação, a não ser indo lá?. E o jornalista não ia. Depois começaram a aparecer jornalistas que se especializaram na questão indígena. Com a criação das assembléias indígenas e, depois, das associações indígenas, surgiram novos temas para as teses de mestrado e de doutorado, outros problemas a resolver. E hoje tem também a contribuição que os antropólogos podem dar como assessores dessas associações ou então na formação de professores indígenas ou na formação de atendentes de enfermagem, essas coisas assim. Eu acho que se ampliou o campo da pesquisa antropológica. Não ficamos só na reconstituição da sociedade como seria no momento do contato, mudou bastante. Mas eu estava dizendo que, no caso dos antropólogos estrangeiros, havia até pouco tempo essa preocupação de ter uma sociedade com pouco contato. E alguns até, curiosamente, recusavam o contato. Eu me lembro que o Johannes Wilbert, ao dirigir uma coleção de mitos de povos da América do Sul, me pediu mitos para os volumes sobre as sociedades Jê e Bororo. Eu peguei mitos que já tinha publicado nos meus livros e artigos e passei para ele, inclusive aqueles contos Krahós que ele publicou em inglês. Os contos Krahós eram doze, ele publicou todos, menos um. Por que ele não publicou este? Eu fui olhar, é a história de como os Krahós ajudaram um fazendeiro a combater os Pukobyê. Então esse ele tirou. Eu falei que também tinha mitos Marubo. Ele respondeu: “Não, eu estou ocupado com os povos marginais". Quer dizer, ele estava utilizando a classificação do Julian Steward. Então Jê é marginal, Marubo não! [risos].

Campos: Nesses mais de trinta anos, desde a conclusão de seu doutorado, a etnologia sofreu uma profunda transformação. No Brasil, seja pelo volume de trabalhos produzidos, que aumentou significativamente, seja pelas discussões teóricas que ocorreram, a etnologia acabou se tornando bem especializada dentro da própria Antropologia. Quais as suas impressões sobre isso?

Júlio Cezar Melatti: Tudo é legitimo, não sei dar uma opinião sobre o que é melhor e o que é pior. Eu acho que continua sendo importante para a formação do pesquisador fazer o seu trabalho de campo - não só com indígenas -, o contato empírico.

Campos: A Antropologia no Brasil vive hoje alguns dilemas: de um lado tem-se uma formação que prioriza o perfil acadêmico, de outro lado tem-se uma demanda cada vez maior por trabalhos técnicos nos quais é exigida 
a participação de antropólogos na elaboração de laudos periciais de diferentes naturezas. Diante desse quadro, como o senhor vê a questão da profissionalização da Antropologia, principalmente no que diz respeito à criação de cursos de graduação e de cursos de pós-graduação profissionalizantes?

Júlio Cezar Melatti: Quando se deseja um laudo pericial referente a indígenas, quilombolas ou o que quer que seja, geralmente um antropólogo de mais idade, de mais experiência não se propõe a ir. Quem vai é o jovem. $E$ às vezes até com pouca formação. É estudante que vai. Então eu acho que ele precisa se formar para isso. E talvez ele não tenha mesmo interesse em desenvolver uma formação mais teórica. É preciso um antropólogo mais prático para resolver essas coisas. O que acontece muito é que - e às vezes é até um problema - o estudante faz esses trabalhos e depois quer aproveitá-los na sua tese. Às vezes faz bem, às vezes não, às vezes tem toda uma formação que permite transformar esse trabalho em texto acadêmico, outras vezes ele perde tempo nisso e os seus prazos na universidade. Então uma formação nesse sentido talvez seja uma solução, não sei.

Campos: Em que o senhor está trabalhando atualmente e quais são seus projetos para o futuro? O senhor esteve com os Krahó pela última vez em 1971 e entre os Marubo em 1983. Sente saudades dos períodos em que as viagens a campo eram corriqueiras e longas?

Júlio Cezar Melatti: Esta é a pergunta mais difícil. Eu acho que deixei de ir a campo depois da última vez em que fui aos Marubos. Eu estava mais ou menos resolvido a não ir mais. Na verdade eu tenho um limite: o meu limite é a língua indígena. Eu tenho dificuldade em aprender. E a pesquisa de campo se desenvolve bem enquanto eu posso prescindir da língua indígena, lançar mão de intérpretes ou coisa assim. Quando chego a certos problemas em que a língua se impõe, a barreira começa a se levantar. E eu vejo que aí eu chego no meu ponto. Aconteceu isso com Krahó, aconteceu isso com Marubo e eu acho que não preciso que isso me aconteça mais vezes. Então resolvi parar e fazer outra coisa. E como uma das áreas em que eu dei certo foi na divulgação, optei por ficar nessa área e tenho feito trabalhos nesse sentido. Comecei a dar esses cursos de extensão sobre áreas etnográficas de certa maneira para me obrigar a escrever sobre elas. E continuo a fazer, talvez com um ritmo mais atenuado atualmente, mas eu fiz as áreas da América do Sul. Todas deixam a desejar, algumas são apenas esboçadas. E eu também estou querendo avançar um pouco mais e ir para a América do Norte. Não fisicamente, mas nesse trabalho das áreas. Recentemente escrevi alguma coisa sobre a América Central e descobri algo que o Julian Steward já sabia e que outras pessoas já sabiam, mas que eu ainda não tinha me dado conta: é que a América Central, do ponto de vista da etnografia e lingüística indígena, é América do Sul. O Panamá, a Costa Rica, o lado caribenho da Nicarágua e de Honduras é América do Sul. Já a parte do Pacífico, a partir de Costa Rica para o norte - El Salvador, Honduras, Guatemala já quase inteira -, aí já é Meso-América, é América do Norte. É curioso que as famílias lingüísticas da América do Norte vão até o México, até Guatemala, um pouco Honduras. As famílias lingüísticas da América do Sul sobem pela América Central: chibcha, chocó, aruaque, vão por aí. Então o limite da América do Sul e América 
do Norte está aí. Então eu fiz mais uma área da América do Sul sobre a América Central. E isso aí eu já pus na divulgação. Trabalhei um pouco recentemente também lendo e escrevendo sobre a Meso-América. Agora estou escrevendo sobre o sudoeste da América do Norte, mas ainda estou esboçando, não estou conseguindo avançar muito. Eu queria, acho, fazer o continente todo. É o que eu estou querendo fazer. Então essa opção também de entrar para divulgação é como que uma fuga do campo. Não sei, são os limites que eu tenho, não consegui superar, eu acho que dou mais rendimento fazendo outra coisa.

Campos: Mas tem uma saudade do campo, daqueles períodos? O senhor gostava de fazer pesquisa de campo, de estar entre os Krahó, ou entre os Marubo?

Júlio Cezar Melatti: Para dizer francamente, eu ia a campo com a intenção de ir embora [risos]. O que vou fazer? É claro que me acostumava. Eu ia para ficar um determinado período, aquele período eu agüentava. Se tivesse que demorar um pouco eu sentia... Certas coisas eu suporto bem em campo e outras não. Então, Krahó era ótimo em matéria de clima, era quente, não tinha mosquito, não era preciso dormir com mosquiteiro. Em rede eu dormia, mas não era preciso pôr mosquiteiro e outras coisas assim. Podia andar só de bermuda, não tinha problema nenhum. Entre os Marubos tinha que andar de camisa de manga comprida, tinha que passar repelente no rosto, nas mãos. Depois o repelente começa a melar o plástico da caneta, a caneta começa a escorregar, é um negócio horrível. Marubo ainda tinha uma vantagem: eles estão no alto, só tinha o mosquito diurno, que era o maruim. Maruim é quase invisível, parece um pó. De noite não tinha mosquito. Com os Marubos lá no alto dos rios não precisava usar mosquiteiro. Tirando isso não existem problemas, as pessoas são boas.

Curitiba, 25 de novembro de 2005. 


\section{NOTAS}

N.F. Também participaram da elaboração do roteiro preliminar da entrevista a antropóloga Carmen Lúcia da Silva, à época pesquisadora do Museu de Arqueologia e Etnologia da UFPR e atualmente professora adjunta da Universidade Federal do Mato Grosso; e Zélia Maria Bonamigo, jornalista e mestre em Antropologia Social pela UFPR. 